\title{
Examination of Classroom Management Approaches of Social Studies Teachers
}

\author{
Selma Güleç ${ }^{1} \&$ Nazlı Durmuş ${ }^{2}$ \\ ${ }^{1}$ Faculty of Education, Uludag University, Bursa, Turkey \\ ${ }^{2}$ Classroom Teacher, Ankara, Turkey \\ Correspondence: Selma Güleç, Faculty of Education, Uludag University, Bursa, Turkey.
}

Received: July 17, 2019 Accepted: August 25, $2019 \quad$ Online Published: October 25, 2019

doi:10.5539/ies.v12n11p139

URL: https://doi.org/10.5539/ies.v12n11p139

\begin{abstract}
In this study, the v0iews of social studies teachers about the autocratic, democratic and irrelevant classroom management approaches were examined. For this purpose, it was investigated whether the opinions of the social studies teachers about the classroom management approaches differed according to their gender and seniority. This research employed a descriptive research model. The sample of the study consisted of 83 teachers working in various schools in Bursa. In this study, the "teachers' understanding of classroom management survey" developed by Terzi and composed of two sections and a total of 38 items was used. The data of the study was analyzed in the SPSS program by using the significance level of .05. By using one-sample t-test in the pairwise comparisons, it was aimed to determine whether there was a difference between the teachers' classroom management understandings and their personal characteristics. In the comparison of more than two sets, one-way analysis of variance was applied. As a result of the study, no significant difference was found between the social studies teachers' classroom management approaches according to the variable of gender. The female and the male social studies teachers demonstrated their autocratic, democratic and irrelevant classroom management understandings at the same level. According to the variable of professional seniority, it was found out that the teachers with a professional seniority of between 16-20 years exhibited their democratic classroom management approaches at a higher level.
\end{abstract}

Keywords: social studies teacher, classroom management, classroom management understanding

\section{Introduction}

The common point of different definitions of the word 'education' is that they define it as a whole of activities aiming to modify or develop behaviors (Başar, 2003). A great majority of educational activities carried out with the aim of developing behaviors are realized by schools, which are special environments established for educational purposes. School is the shared name of the institutions undertaking the function of educating individuals in a society (Çalık, 2003). This special environment called 'school' has three functions. The first is to protect students against the difficulties of the external environment and make life easier for students; the second is to clean students' behaviors by keeping undesirable behaviors, which can be easily encountered in the external environment; the third is to create a balance within its borders by not allowing for the exhibition of social differences existing in the environment outside the school.

Classroom is the environment where students and teachers share their knowledge and experiences via various means of communication with the aim of reaching educational purposes with an appropriate configuration (Başar, 2003). It is teachers that are primarily responsible for the realization of experiences in the classroom in the direction of pre-determined purposes. The teacher is the person who is charged with having students reaches objectives specified in an education program. Therefore, teachers have a great effect on outcomes reached during education. The quality of a teacher and the behaviors which $\mathrm{s} / \mathrm{he}$ exhibits in the classroom are of importance in terms of how much students reach their goals. The teacher's fulfilling students' needs and expectations increases the quality of education. The planning, organization and management of experiences in a classroom is realized under the responsibility of the teacher (Aydın, 2012).

In the realization of educational purposes, the most important dimension in terms of functionality is the management of the classroom (Özel \& Bayındır, 2008). Good management of a classroom is accepted as the first 
step to become successful in education. For this reason, the leadership role of the teacher has risen to prominence and his/her knowing group dynamism has gained importance. In a sense, those who are successful at classroom management generally bear good teacher qualities (Demirel, 2005).

In order for a teacher to manage a classroom effectively, s/he is expected to exhibit some behaviors. These are knowing students' personal and psychological needs, establishing a positive communication among students, creating a positive classroom atmosphere, and controlling negative student behaviors. The attitude which a teacher exhibits in the regulation of the learning environment, creation of the classroom atmosphere and the management of student behaviors is of critical importance in terms of the outputs of education (Oliver \& Reschly, 2007).

Classroom management initially referred to a teacher's establishing his/her authority in the classroom and was an understanding based on discipline (Çalık, 2003). However, today, classroom management does not only mean a teacher's establishing his/her authority in the classroom, but it also means creating a classroom environment achieving more learning. In the effective classroom management, since students spend more time on learning, there appears a decrease in the number non-learning behaviors. For, in the effective classroom, all activities are purposeful, organized and realized in a disciplined environment (Tertemiz, 2003). Positive classroom atmosphere increases students' academic success (Gordon, 2003). In order to reach educational and instructional goals, teachers need to be skillful and have a say in classroom management. For, in order to bring students' behaviors to a desired level and meet the demands and the needs of a society, effective classroom management is required (Özsoy, 2003).

Classroom management is defined as the realization of activities achieving academic, emotional and social development of students (Evertson \& Weinstein, 2006). Classroom management covers such operational processes as arranging the physical structure of the classroom, guiding and controlling the participation in learning experiences and modifying behaviors hindering the participation in learning experiences in a way to have students respect themselves, acquire new behaviors and become productive (Özyürek, 2005).

Classroom management can also be defined as the synthesis of the answers to be given to the questions of "What is going to be done?" and "How is it going to be done?" A good classroom management makes a student feel responsible for his/her behaviors. There is no force underlying this phenomenon, but instead, there is persuasion, knowledge and reason (Özsoy \& Ataünal, 2001).

The most important factor affecting classroom management is the teacher. For this reason, it can be stated that an effective classroom management is achieved via an effective teacher. A teacher as an effective classroom manager is expected to prepare the classroom for education, determine and teach the classroom rules and processes, organize and maintain learning and have students behave appropriately. In an effectively-managed classroom, while students show a high level of interest in the given task, they exhibit distracting behaviors at a low level and most of the teaching time is used for educational purposes (Harris, 1991, cited by Başar, 2003).

Classroom management covers a wide area of activities performed by teachers such as regulating the physical environment, describing and practicing the classroom procedures, observing students' behaviors, coping with undesired behaviors, using the time effectively and motivating students to the lesson, teaching lessons in a way to encourage students to undertake the responsibility of their learning and take charge (Watkins \& Wagner, 2000).

As for the management of the classroom and the creation of an appropriate learning environment, the teacher is supposed to show how to behave in the classroom and achieve learner awareness. The work of managing a classroom requires a separate skill and knowledge accumulation. For this reason, teachers' classroom management understandings and practicing steps related to these understandings affect their students and learning experiences, that is to say, their classroom management styles (Özel \& Bayındır, 2008).

Teachers' management understandings can be classified as autocratic, democratic and indifferent according to leadership characteristics which they have adopted.

1) Autocratic Management Understanding: Autocratic leadership is the leadership style showing a high level professional orientation but a low level of human orientation. Teachers with this leadership style make decisions on their own, do not include students in decision-making processes and do not share these with their students (Ounpigul, 2000, cited by Balay, 2003). An autocratic teacher forces students to realize his/her own desires and establishes a control preventing the violation of rules and declining. Rather than motivating students to study, it forces them to study, and when they decline, it punishes them. They have the control in their hands, apply strict rules and take a tough stance (Celep, 2008).

2) Democratic Management Understanding: Democratic leadership is the leadership style directed both at work/duty and human. Teachers having this leadership style make decisions together with the group, share these 
with the group and encourage participation and support students' efforts related to work/duty (Ounpigul, 2000, cited by Balay, 2003).

Teachers having democratic management understanding create a confidence-giving effect on students in the classroom. Students in these classrooms are autonomous. However, this autonomy does not give them the right to do whatever they want. Democratic teachers know the way of laying down rules protecting students' personal rights and putting some restrictions. They are determined, but still, tolerant. They provide their students with a learning environment where solidarity is predominant (Celep, 20008).

3) Indifferent Management Understanding: Indifferent teachers are ineffective when students are working. They are unsuccessful at how to apply critical rules in the classroom. They fall short of developing students' self-discipline habits. They allow students to behave how they want. The climate of the classroom is poor at affecting learning positively. These teachers allow students to behave independently (Celep, 2008).

Indifferent teachers do not consider putting restrictions on students' behaviors, supervising and guiding them; they are permissive, unplanned and unorganized. Indiscipline and chaos predominate in their classrooms. Teachers with indifferent leadership style give information to students only when they ask for; they neither appreciate nor criticize. This kind of teachers cause ruined classroom order, chaos, disappointment in students, stress, low-spiritedness and low productivity and performance (İpek, 1999, cited by Balay, 2003).

This study aimed to investigate the classroom management understandings of the social studies teachers working at different schools. For this purpose, the classroom management understandings of the social studies teachers were examined according to the variables of gender and service length.

\section{Method}

The study is a descriptive one. The population of the study was composed of the social studies teachers working at various schools in Bursa in the 2017-2018 educational year. Of the participant teachers, 67 were female and 16 were male.

\subsection{Data Collection Tool}

In the first section of this questionnaire, necessary information was collected in relation to the gender and service length of the teachers.

The second section of the questionnaire aims to determine the "Teachers' Classroom Management Understandings" included 34 question items. Each item was evaluated by using the five-point Likert type rating scale, namely "Always", "Usually", "Sometimes", "Rarely" and "Never". Each alternative excluding the 16th and the 31 st items was scored as 5, 4, 3, 2, 1 respectively and the 16 th and the 31 st items were scored as 1, 2, 3, 4, 5 respectively.

During the answering process of the questionnaire, with the aim of increasing the reliability of the questionnaire, the 10th and the 16th items and the 21st and the 33rd items were presented in the same way as the control questions. For this reason, since the 16th and the 33rd items were the control items, they were not taken into evaluation.

The items numbered $1,2,3,4,5,6,7,8,9,10$ and 11 were prepared in a way to show how much the teachers exhibited autocratic management understandings; the items numbered 12, 13, 14, 15, 17, 18, 19, 20.21, 22 and 23 were prepared to find out how much the teachers exhibited democratic management understandings; the items numbered $24,25,26,27,28,29,30.31,32$ and 34 were prepared to determine how much the teachers exhibited indifferent management understandings (Terzi, 2001).

\subsection{Data Analysis}

The items aiming to determine the teachers' personal characteristics and classroom management understandings, the frequency and the percentage calculations were made.

In relation to if there was a difference between the teachers' classroom management understandings and their personal characteristics, "one sample t test" was used in the pairwise comparisons and "one-way analysis of variance" was used in the comparisons of more than two samples and also F test analyses were made. Moreover, if the result of the F test statistics was significant as a result of the analysis of variance, the Tukey HSD multiple comparison test was applied with the aim of determining the source of the difference.

In the statistical analyses made in the study, the significant level was accepted as .05 and the statistical analyses of the research data were made by using the SPSS program. 


\section{Findings and Interpretations}

In this section of the study, the findings obtained from the analyses of the data were given in tables and required interpretations were made in relation to them. In the presentation of the findings and the interpretations, the sequence of the questions related to the purpose of the study was followed. For each purpose, firstly, the related table was given and, then, interpretations were made under the same heading.

\subsection{Change of the Social Studies Teachers' Opinions About Their Behaviors Reflecting Their Classroom Management Understandings According to the Variable of Gender}

In this problem, it was aimed to determine if the social studies teachers' autocratic, democratic and indifferent classroom management understandings differed according to the variable of gender. To achieve this purpose of the study, the arithmetic means and the standard deviations of the scores obtained from the items reflecting the teachers' classroom management understanding levels were calculated. The significance of the difference between the calculated arithmetic means and the variable of gender was tested via $t$ test and was presented in Tables 1, 2 and 3.

Table 1. Teachers' opinions about their autocratic classroom management understandings according to the variable of gender

\begin{tabular}{|c|c|c|c|c|c|}
\hline $\begin{array}{c}\text { Autocratic Classroom Management } \\
\text { Understanding }\end{array}$ & $\begin{array}{c}\text { Number of } \\
\text { Subjects } \\
\text { (n) }\end{array}$ & $\begin{array}{c}\text { Arithmetic } \\
\text { Mean } \\
(\bar{X})\end{array}$ & $\begin{array}{c}\text { Standard } \\
\text { Deviation } \\
(\mathrm{s}) \\
\end{array}$ & $\begin{array}{c}\text { " } t \text { " } \\
\text { value } \\
\text { (t) }\end{array}$ & $\begin{array}{c}\text { Significance } \\
\text { Level }\end{array}$ \\
\hline Female & 67 & 2.81 & 0.48 & \multirow{2}{*}{1.602} & \multirow{2}{*}{$<.05$} \\
\hline Male & 16 & 2.59 & 0.59 & & \\
\hline
\end{tabular}

When Table 1 was examined, it was observed in relation to the levels of the teachers' exhibiting the autocratic classroom management understanding that the mean score of the female teachers was 2.81 and that of the male teachers was 2.59. In terms of exhibiting the autocratic classroom management understanding, the female teachers exhibited this understanding at a slightly higher level compared to their male counterparts. According to the variable of gender, the value of 1.602 obtained with the t-test applied between the means of the two groups was smaller than the t-table value according to the significance level of .05. This indicates that the levels of the teachers' exhibiting the autocratic classroom management understanding did not differ significantly according to the variable of gender.

Table 2. Teachers' opinions about their democratic classroom management understandings according to the variable of gender

\begin{tabular}{|c|c|c|c|c|c|}
\hline $\begin{array}{c}\text { Democratic Classroom Management } \\
\text { Understanding }\end{array}$ & $\begin{array}{c}\text { Number of } \\
\text { Subjects } \\
\text { (n) }\end{array}$ & $\begin{array}{c}\text { Arithmetic } \\
\text { Mean } \\
(\bar{X})\end{array}$ & $\begin{array}{c}\text { Standard } \\
\text { Deviation } \\
\text { (s) }\end{array}$ & $\begin{array}{c}\text { "t" } \\
\text { value } \\
(\mathrm{t})\end{array}$ & $\begin{array}{l}\text { Significance } \\
\text { Level }\end{array}$ \\
\hline Female & 67 & 4.32 & 0.36 & \multirow{2}{*}{0.533} & \multirow{2}{*}{$<.05$} \\
\hline Male & 16 & 4.38 & 0.49 & & \\
\hline
\end{tabular}

In Table 2, it was seen in relation to the teachers' exhibiting the democratic classroom management understanding that the mean score of the female teachers was 4.32 and that of the male teachers was 4,38. In terms of exhibiting the democratic classroom management understanding, the mean score of the male teachers was slightly higher than that of the female teachers. The value of 0.533 obtained from the t-test applied between the means of the two groups was smaller than the t-table value according to the significance level of .05. According to this, the female and the male teachers exhibited the democratic classroom management understanding at the same level. 
Table 3. Teachers' opinions about their indifferent classroom management understandings according to the variable of gender

\begin{tabular}{|c|c|c|c|c|c|}
\hline $\begin{array}{c}\text { Indifferent Classroom } \\
\text { Management } \\
\text { Understanding }\end{array}$ & $\begin{array}{l}\text { Number of Subjects } \\
\text { (n) }\end{array}$ & $\begin{array}{l}\text { Arithmetic Mean } \\
\qquad(\bar{X})\end{array}$ & $\begin{array}{c}\text { Standard Deviation } \\
\text { (s) }\end{array}$ & $\begin{array}{l}\text { "t" value } \\
(t)\end{array}$ & Significance Level \\
\hline Female & 67 & 2.16 & 0.35 & \multirow{2}{*}{1.611} & \multirow{2}{*}{$<.05$} \\
\hline Male & 16 & 2.31 & 0.28 & & \\
\hline
\end{tabular}

When Table 3 was examined, it was seen in relation to the teachers' exhibiting the indifferent classroom management understanding that the mean score of the female teachers was 2.16 and that of the male teachers was 2.31. According to this, it can be stated that the male teachers exhibited the indifferent classroom management understanding slightly more frequently than their female counterparts. The value of 1.611 obtained from the $t$-test applied to test the significance of the difference between the female and the male teachers was smaller than the table value according to the significance level of .05. According to this, it can be stated that the levels of the female and the male teachers' exhibiting the indifferent classroom management understanding did not differ significantly.

3.2 Change of the Social Studies Teachers' Opinions About Their Behaviors Reflecting Their Classroom Management Understandings according to the Variable of Length of Professional Service

Directed at this purpose of the study, it was aimed to determine if the teachers' opinions about their classroom management understandings differed according to their professional service lengths. To achieve this purpose of the study, the arithmetic means and the standard deviations of the scores obtained in relation to the levels of the teachers' exhibiting autocratic, democratic and indifferent classroom management understandings were calculated. The significance of the difference between the arithmetic means of the teachers' classroom management understandings was tested via one-way analysis of variance (ANOVA). According to the variable of professional service length, the arithmetic means, the standard deviations and the ANOVA results were given in Tables 4, 5 and 6.

Table 4. Teachers' opinions about their autocratic classroom management understandings according to their professional service lengths

\begin{tabular}{cccc}
\hline Autocratic Classroom Management Understanding (Length of Professional & $\begin{array}{c}\text { Number of } \\
\text { Subjects } \\
\text { Service) }\end{array}$ & $\begin{array}{c}\text { Arithmetic } \\
\text { Mean } \\
(\bar{X})\end{array}$ & $\begin{array}{c}\text { Standard } \\
\text { Deviation } \\
(\mathrm{s})\end{array}$ \\
\hline 5 years or less & 11 & 2.56 & 0.53 \\
$6-10$ years & 23 & 2.80 & 0.40 \\
$11-15$ years & 18 & 2.78 & 0.48 \\
$16-20$ years & 19 & 2.78 & 0.62 \\
21 years and over & 12 & 2.83 & 0.54 \\
\hline
\end{tabular}

Table 5. One-Way ANOVA results of the teachers' opinions about their autocratic classroom management understandings according to the variable of professional service length

\begin{tabular}{ccccc}
\hline Autocratic Classroom Management & $\begin{array}{c}\text { Sum of } \\
\text { Squares } \\
\text { Understanding }\end{array}$ & $\begin{array}{c}\text { Degree of } \\
\text { Freedom } \\
(\mathrm{SS})\end{array}$ & $\begin{array}{c}\text { Mean of } \\
\text { Squares } \\
(\mathrm{ms})\end{array}$ & $\begin{array}{c}\text { F } \\
\text { value } \\
(\mathrm{F})\end{array}$ \\
\hline Between Groups & 0.551 & 4 & 0.138 & 0.262 \\
Within Groups & 20.442 & 78 & 82 & 0.526 \\
Total & 20.994 & 8.05 & \\
\hline
\end{tabular}

In Table 4, it was seen that the arithmetic means of the scores related to the levels of the teachers' exhibiting the autocratic classroom management understanding according to the lengths of their professional service were 2.56 for the teachers with a service length of 5 years and less, 2.80 for the ones with a service length of 6-10 years, 2.78 for the ones with a service length of 11-15 years, 2.78 for the ones with a service length of 16-20 years and 2.83 for the ones with a service length of 21 years and over. According to the length of service, it can be stated that while the teachers with a service length of 21 years and over had the highest arithmetic mean, the ones with a service 
length of 5 years and less had the lowest arithmetic mean in terms of exhibiting the autocratic classroom management understanding.

The $\mathrm{F}$ value obtained as a result of the one-way analysis of variance made with the aim of testing the statistical significance of the difference between the mean scores related to the levels of the teachers' exhibiting the autocratic classroom management understanding was 0.526 . Since $F$ value was smaller than the F table value, the difference between the mean scores related to the autocratic classroom management was not significant according to the significance level of .05 .

Table 6. Teachers' opinions about their democratic classroom management understandings according to their professional service lengths

\begin{tabular}{cccc}
\hline $\begin{array}{c}\text { Democratic Classroom Management Understanding (Length of Professional } \\
\text { Service) }\end{array}$ & $\begin{array}{c}\text { Number of } \\
\text { Subjects } \\
(\mathrm{n})\end{array}$ & $\begin{array}{c}\text { Arithmetic } \\
\text { Mean } \\
(\bar{X})\end{array}$ & $\begin{array}{c}\text { Standard } \\
\text { Deviation } \\
(\mathrm{s})\end{array}$ \\
\hline 5 years or less & 11 & 4.24 & 0.47 \\
$6-10$ years & 23 & 4.13 & 0.36 \\
$11-15$ years & 18 & 4.41 & 0.30 \\
$16-20$ years & 19 & 4.50 & 0.34 \\
21 years and over & 12 & 4.39 & 0.40 \\
\hline
\end{tabular}

Table 7. One-Way ANOVA results of the teachers' opinions about their democratic classroom management understandings according to the variable of professional service length

\begin{tabular}{ccccc}
\hline $\begin{array}{c}\text { Democratic Classroom Management } \\
\text { Understanding }\end{array}$ & $\begin{array}{c}\text { Sum of } \\
\text { Squares } \\
(\mathrm{SS})\end{array}$ & $\begin{array}{c}\text { Degree of } \\
\text { Freedom } \\
(\mathrm{df})\end{array}$ & $\begin{array}{c}\text { Mean of } \\
\text { Squares } \\
(\mathrm{ms})\end{array}$ & $\begin{array}{c}\text { F } \\
\text { value } \\
(\mathrm{F})\end{array}$ \\
\hline Between Groups & 1.685 & 4 & 0.421 & 0.135 \\
Within Groups & 10.544 & 78 & 8.116 \\
Total & 12.229 & 82 & $<.05$ \\
\hline
\end{tabular}

In Table 6, it was seen that the arithmetic means of the scores related to the levels of the teachers' exhibiting the democratic classroom management understanding according to the lengths of their professional service were 4.24 for the teachers with a service length of 5 years and less, 4.13 for the ones with a service length of 6-10 years, 4.41 for the ones with a service length of 11-15 years, 4.50 for the ones with a service length of 16-20 years and 4.39 for the ones with a service length of 21 years and over. According to the length of service, it can be stated that while the teachers with a service length of 16-20 years had the highest arithmetic mean, the ones with a service length of 6-10 years had the lowest arithmetic mean in terms of exhibiting the democratic classroom management understanding.

The $\mathrm{F}$ value obtained as a result of the one-way analysis of variance made with the aim of testing the statistical significance of the difference between the mean scores related to the levels of the teachers' exhibiting the democratic classroom management understanding was 3.116. Since F value was bigger than the F table value, the differences between the mean scores related to the democratic classroom management were significant according to the significance level of .05 .

Table 8. Teachers' opinions about their indifferent classroom management understandings according to their professional service lengths

\begin{tabular}{cccc}
\hline $\begin{array}{c}\text { Indifferent Classroom Management Understanding (Length of Professional } \\
\text { Service) }\end{array}$ & $\begin{array}{c}\text { Number of } \\
\text { Subjects } \\
(\mathrm{n})\end{array}$ & $\begin{array}{c}\text { Arithmetic } \\
\text { Mean } \\
(\bar{X})\end{array}$ & $\begin{array}{c}\text { Standard } \\
\text { Deviation } \\
(\mathrm{s})\end{array}$ \\
\hline 5 years or less & 11 & 2.41 & 0.34 \\
6-10 years & 23 & 2.17 & 0.36 \\
$11-15$ years & 18 & 2.12 & 0.29 \\
$16-20$ years & 19 & 2.09 & 0.33 \\
21 years and over & 12 & 2.25 & 0.33 \\
\hline
\end{tabular}


Table 9. One-way ANOVA results of the teachers' opinions about their indifferent classroom management understandings according to the variable of professional service length

\begin{tabular}{ccccc}
\hline $\begin{array}{c}\text { Indifferent Classroom Management } \\
\text { Understanding }\end{array}$ & $\begin{array}{c}\text { Sum of } \\
\text { Squares } \\
(\mathrm{SS})\end{array}$ & $\begin{array}{c}\text { Degree of } \\
\text { Freedom } \\
(\mathrm{df})\end{array}$ & $\begin{array}{c}\text { Mean of } \\
\text { Squares } \\
(\mathrm{ms})\end{array}$ & $\begin{array}{c}\text { F } \\
\text { value } \\
(\mathrm{F})\end{array}$ \\
\hline Between Groups & 0.838 & 4 & 0.209 & 0.111 \\
Within Groups & 8.652 & 78 & 82 & 1.888 \\
Total & 9.490 & $(\mathrm{p})$ & \\
\hline
\end{tabular}

In Table 8, it was seen that the arithmetic means of the scores related to the levels of the teachers' exhibiting the democratic classroom management understanding according to the lengths of their professional service were 2.41 for the teachers with a service length of 5 years and less, 2.17 for the ones with a service length of 6-10 years, 2.12 for the ones with a service length of 11-15 years, 2.09 for the ones with a service length of 16-20 years and 2.25 for the ones with a service length of 21 years and over. According to the length of service, it can be stated that while the teachers with a service length of 5 years and less had the highest arithmetic mean, the ones with a service length of 16-20 years had the lowest arithmetic mean in terms of exhibiting the indifferent classroom management understanding.

It was seen that the F value obtained as a result of the one-way analysis of variance made in relation to the teachers' exhibiting the indifferent classroom management understanding was 1.888 . Since this value was smaller than the $\mathrm{F}$ table value, the difference between the scores related to the indifferent classroom management was not significant according to the significance level of .05 .

Based on these findings, it can be stated that the levels of the teachers' exhibiting the autocratic and the indifferent classroom management understandings did not differ, but the levels of their exhibiting the democratic classroom management understanding differed according to the variable of professional service length. The results of the Tukey HSD applied to determine the groups from which this difference observed in the level of the teachers' exhibiting the democratic classroom management understanding resulted according to the variable of professional service length were given in Table 10 .

Table 10. Tukey HSD results of the teachers' opinions about their democratic classroom management understandings according to the variable of professional service length

\begin{tabular}{ccccc}
\hline Professional Service Length & $6-10$ years & $11-15$ years & $16-20$ years & 21 years and over \\
\hline 5 years and less & .105 & .169 & .263 & .147 \\
6-10 years & - & .275 & $.368^{*}$ & .252 \\
$11-15$ years & - & - & .093 & .023 \\
$16-20$ years & - & - & - & .116 \\
\hline
\end{tabular}

According to Table 10, it was seen that the difference in relation to the levels of the exhibition of the democratic classroom management understanding was between the teachers with a service length of 6-10 years and the ones with a service length of 16-20 years. Based on these findings, it can be stated that the teachers with a service length of 16-20 years exhibited the democratic classroom management understanding at a higher level compared to the ones with a service length of 6-10 years.

\section{Conclusion and Suggestions}

In this study aiming to determine the teachers' opinions about their autocratic, democratic and indifferent classroom management understandings which they exhibited in their classes, the following conclusions were reached.

The opinions of the social studies teachers about their autocratic, democratic and indifferent classroom management understandings did not differ significantly according to the variable of gender. That is to say, the female and the male teachers exhibited their autocratic, democratic and indifferent classroom management understandings at the same level.

The teachers' opinions about their autocratic and indifferent classroom management understandings did not differ significantly according to the variable of professional service length. That is to say, the teachers included in the determined 5 service length groups exhibited the autocratic and the indifferent classroom management 
understandings at similar levels.

The teachers' opinions about their democratic classroom management understandings differed according to the variable of professional service length. That is to say, the teachers with a service length of 16-20 years exhibited the democratic classroom management understanding at a higher level compared to the ones with a service length of 6-10 years.

Based on the findings of the study, the suggestions in relation to the development of the democratic life culture in the classroom were presented below:

- Works can be done to help teachers develop their democratic classroom management understandings and personal development programs should be prepared.

- In education faculties, applied educational activities should be organized in order to develop preservice teachers' democratic attitudes and behaviors. To achieve this, practice schools should be opened in education faculties and preservice teachers should be given the opportunity to develop their democratic classroom management skills with the help of practices in these schools.

- In the "Classroom Management" course given in education faculties, the positive effects of the democratic classroom management understanding on students should be emphasized. Moreover, teachers and preservice teachers should be given the leadership education included within the subjects of classroom management.

- Teachers' educational needs should be determined and they should be helped to develop. To achieve this, in-service training seminars should be organized by the Ministry of National Education in a systematic way for teachers with the aim of creating democratic classroom culture.

- Education programs should be prepared within the framework of democratic education principles. Especially courses on democracy and human rights should be given in all the educational stages starting from the first years of primary education.

\section{References}

Aydın, A. (2012). Sinıf Yönetimi (15. Baskı). Ankara: Pegem Yayınları.

Balay, R. (2003). 2000'li Yıllarda Sinıf Yönetimi (2. Basım). Ankara: Sandal Yayınları.

Başar, H. (2003). Sınıf Yönetimi (10. Baskı). Ankara: Anı Yayıncılık

Çalık, T. (2003). Eğitimde Stratejik Planlama Ve Okulların Stratejik Planlama Açısından Nitel Değerlendirmesi. Gazi Üniversitesi Kastamonu Eğitim Dergisi, 11(2), 251-268.

Celep, C. (2008). Sinıf Yönetiminde Kuram ve Uygulama (4. Baskı). Ankara: Pegem Yayınları.

Demirel, Ö. (2005). Öğretimde Planlama ve Değerlendirme (Öğretme Sanatı) (8. Bask1). Ankara: Pegem Yayınları.

Demirtaş, H. (2005). Sinıf Yönetiminin Temelleri. H. Kıran (Editör). Etkili Sınıf Yönetimi. Ankara: Anı Yayıncilik.

Evertson, C. M., \& Weinstein, C. (2006). Classroom Management as a Field of Inquiry. In C. M. Evertson, \& C. Weinstein (Eds.), Handbook of Classroom Management: Research, Practice, and Contemporary Issues. Mahwah, NJ: Lawrence Erlbaum Associates, Inc.

Gordon, T. (2003). Teacher Effectiveness Training (1st rev. ed.). New York: Three Rivers Press.

Oliver, R. M., \& Reschly, D. J. (2007). Effective Classroom Management: Teacher Preparation and Professional Development.

Özel, A., \& Bayındır, N. (2008). Yapılandırmacı Anlayıı̧a Göre Sinıf Yönetimi. Ankara: Pegem Akademi.

Özsoy, H. İ., \& Ataünal, A. (2001). Nasıl Bir İnsan ve Nasıl? Ankara: 20 Mayıs Eğitim, Kültür ve Sosyal Dayanışma Vakfı Yayını.

Özsoy, O. (2003). Etkin Öğretmen,Etkin Öğrenci, Etkin Öğretim. İstanbul: Hayat Yayınc1lık.

Özyürek, M. (2005). Olumlu Sinıf Yönetimi. Ankara: Kök Yayıncılık

Tertemiz, N. (2003). Sinıf Yönetimi ve Disiplin. Küçükahmet, L. (Ed.), Sınıf yönetimi. Ankara: Nobel Yayınları.

Terzi, Ç. (2001) Öğretmenlerin Sinıf Yönetimi Anlayışlarına İlişkin Görüşlerinin Belirlenmesi. Yüksek Lisans Tezi, Anadolu Üniversitesi Eğitim Bilimleri Enstitüsü, Eskişehir.

Watkins, C., \& Wagner, P. (2000). Improving School Behaviour. London: Paul Chapman Publishing. 


\section{Copyrights}

Copyright for this article is retained by the author(s), with first publication rights granted to the journal.

This is an open-access article distributed under the terms and conditions of the Creative Commons Attribution license (http://creativecommons.org/licenses/by/4.0/). 